\title{
Further Studies of the Rachitogenic Effect of Dried Yeast in Pig Diets
}

\author{
By R. BRAUDE, K. M. HENRY AND S. K. KON \\ National Institute for Research in Dairying, University of Reading .
}

(Received 27 February 1948)

In previous papers Braude, Kon \& White (1943, 1944) described the development of rickets in fattening pigs on diets containing a large proportion of yeast, its cure or complete prevention with vitamin $\mathrm{D}$, and its partial prevention with additional calcium salts. The yeast was added as a protein supplement to normal fattening rations to the extent of $8-20 \%$. The cause of the rickets remained obscure, though it was unlikely (Braude $e t$ al. 1944) that it was due to the high phossphorus content of the yeast.

The present paper describes further attempts to determine the nature of the rachitogenic factor, some of them, including a test of stability of the factor to heat, made some time ago, others recent, dealing with the possible connexion between the rachitogenic effect and the phytate phosphorus content of the diet.

Practical rations for pigs, because of their high cereal content, are relatively rich in phytic acid; this is normally hydrolysed in the gut by the phytase present in the majority of cereals (Pedersen, I940; Møllgaard, r946). It seemed possible that yeast might in some way inhibit the hydrolysis of phytic acid in the diet and that this would affect the availability to the pig of calcium and phosphorus and lead to rickets. Experiments were therefore planned to test this point. In the meantime Hoff-Jørgensen (1947) published results of experiments in vitro supporting the view that brewer's yeast inhibited phytase activity.

\section{EXPERIMENTAL}

Exp. 6.* Autoclaved yeast, irradiated yeast and yeast residue in relation to yeast rickets in pigs

\section{Selection of animals}

Large White pigs, IO-I I weeks old, from five litters were divided into five blocks of six pigs, and a pig from each block was allocated by toss of coin to one of the six diets described below.

Diets

The composition of the diets is given in Table $I$ and their chemical analysis in Table 2. They were given as a wet mash in the way and in the quantities described by Braude et al. (1943).

(1) Rachitogenic diet. This was the $20 \%$ yeast diet of Braude et al. (1943, 1944). The dried brewer's yeast was purchased from Messrs A. Guinness, Son and Co. Ltd.

- Exps. 1-5 have already been described by Braude et al. (1943, 1944). 
(2) Autoclaved yeast diet. This was the same as diet I with the yeast autoclaved for $6 \mathrm{hr}$. at $120^{\circ}$. The purpose of this change was to find out whether the factor causing rickets was stable to heat.

Table 1. Percentage composition of diets used in Exp. 6

Component
Wheat feed
Barley meal
Ground oats
Dried grass
Dried yeast
Autoclaved dried yeast
Dried yeast residue
Fish meal
Calcium carbonate
Salt

\begin{tabular}{|c|c|c|c|}
\hline \multicolumn{4}{|c|}{ Diet no. } \\
\hline r, $3^{*}$ and $s t$ & 2 & 4 & 6 \\
\hline 35 & 35 & 35.5 & 47 \\
\hline 20 & 20 & 20 & 20 \\
\hline 20 & 20 & 20 & 20 \\
\hline 3 & 3 & 3 & 3 \\
\hline 20 & - & - & - \\
\hline- & 20 & - & - \\
\hline- & $\longrightarrow$ & 20 & $\rightarrow$ \\
\hline$\cdots$ & - & - & 10 \\
\hline I. 5 & $1 \cdot 5$ & $I \cdot 5$ & - \pm \\
\hline 0.5 & 0.5 & $-t$ & -1 \\
\hline
\end{tabular}

- Diet 3 was as diet I but with $2 \mathrm{~g}$./pig daily of irradiated yeast added directly to the trough. + Diet 5 was as diet 1 but with 2.5 parts of sodium bicarbonate replacing $1 \cdot 5$ parts of calcium carbonate.

$\ddagger$ Not added to the diet as sufficient is provided by dried yeast residue or fish meal.

Table 2. Analytical data for diets used in Exp. 6 and for their components

$\begin{array}{lcccccccc}\text { Diet or component } & \begin{array}{c}\text { Moisture } \\ (\%)\end{array} & \begin{array}{c}\text { Crude } \\ \text { protein } \\ (\%)\end{array} & \begin{array}{c}\text { Ether } \\ \text { extract } \\ (\%)\end{array} & \begin{array}{c}\text { Carbo- } \\ \text { hydrate } \\ (\%)\end{array} & \begin{array}{c}\text { Fibre } \\ (\%)\end{array} & \begin{array}{c}\text { Ash } \\ (\%)\end{array} & \begin{array}{c}\text { Ca } \\ (\%)\end{array} & \begin{array}{c}\mathbf{P} \\ (\%)\end{array} \\ \text { Wheat feed } & 11.4 & 13.4 & 4.0 & 53.1 & 12.7 & 5.4 & 0.12 & \mathbf{1 \%} \\ \text { Barley meal } & 13.8 & 11.2 & 1.6 & 66.8 & 4.3 & 2.3 & 0.06 & 0.34 \\ \text { Ground oats } & 13.0 & 12.0 & 3.8 & 57.2 & 11.3 & 2.7 & 0.10 & 0.33 \\ \text { Dried grass } & 11.7 & 7.2 & 2.5 & 48.6 & 23.4 & 6.6 & 0.67 & 0.18 \\ \text { Dried yeast } & 9.4 & 47.4 & 0.3 & 32.4 & - & 10.5 & 0.27 & 2.32 \\ \text { Dried yeast residue } & 16.4 & 32.3 & 3.8 & 35.1 & - & 12.4 & 0.04 & 1.59 \\ \text { Fish meal } & 10.2 & 62.3 & 6.2 & - & - & 21.8 & 6.46 & 3.67 \\ \text { Diets 1, 2, 3 and 5. } & 11.8 & 19.1 & 2.6 & 51.3 & 8.3 & 6.9 & 0.73 & 0.96 \\ \text { Diet 4 } & 13.0 & 16.1 & 3.3 & 52.0 & 8.3 & 7.3 & 0.68 & 0.81 \\ \text { Diet 6 } & 12.1 & 17.4 & 3.7 & 51.2 & 9.7 & 5.9 & 0.74 & 0.98\end{array}$

- The composition of the diets is calculated from that of the components. The autoclaved yeast used in diet 2 came from the same batch as the dried yeast and was not analysed again after autoclaving. The irradiated yeast added to diet 3 and the sodium bicarbonate added to diet 5 are not included in these figures.

(3) Irradiated yeast diet. This was diet I supplemented with $2 \mathrm{~g}$. irradiated yeast/pig daily. A sample of the dried brewer's yeast was finely ground so that $70 \%$ of it passed through a 100 mesh sieve and $2 \mathrm{~kg}$. of it were spread as evenly as possible over a circle $6 \frac{\mathrm{f}}{\mathrm{ft}}$. in diameter marked out on a large sheet of glazed paper. Over the centre of this circle, and $30 \mathrm{in}$. from it, a quartz mercury-vapour lamp was suspended. After $20 \mathrm{~min}$. irradiation the powder was collected and the operation repeated twice, i.e. the yeast was irradiated in all for $\mathrm{I}$ hr. The vitamin D potency of the irradiated yeast was not determined, but from results obtained under similar conditions by Booth (1934) it can be gauged that it was not less than $500 \mathrm{i} . \mathrm{u}$./g. As the addition of a small quantity of rradiated yeast would be convenient under practical conditions, the mixture was 
tested to find out whether it would make safe the feeding of large quantities of dried yeast to pigs.

(4) Yeast-residue diet. The yeast in diet I was replaced by $20 \%$ of the residue remaining in the preparation of a proprietary yeast extract. As special fractionation of yeast in quantities required in experiments with pigs was impossible for practical reasons, the giving of this residue, which was made available to us by Phillips Yeast Products Ltd., London, was undertaken in an endeavour to locate the factor in yeast responsible for rickets.

(5) Yeast diet with sodium bicarbonate. This was diet I with $\mathrm{r} \cdot 5 \%$ calcium carbonate replaced by $2.5 \%$ sodium bicarbonate. Earlier work had shown the beneficial effect of calcium carbonate in preventing yeast rickets. This was most probably due to calcium as such, but it was thought desirable to check whether the effect was in any way connected with the alkaline nature of the supplement.

(6) Fish-meal diet. This was a normal fattening ration, with fish meal as a protein supplement, used for purposes of comparison with the yeast diets.

\section{Experimental details}

The main experiment lasted 24 weeks and records of growth and food intake were kept. With a few animals the feeding was extended beyond 24 weeks for reasons given below. Blood samples were taken at the beginning of the experiment, after 12 weeks and after 24 weeks, and the serum calcium was determined by the Clark \& Collip (1925) modification of the Kramer \& Tisdall (1921) method. The $\mathrm{pH}$ of the intestinal contents of two blocks of pigs was determined at slaughter by means of a glass electrode.

\section{Results}

The pigs in the first three blocks completed the experiment without any disturbance. In blocks 4 and 5 five pigs died rather suddenly during a fortnight in February in which abnormally cold weather was experienced. At the time of death some of them were already affected by the experimental treatments, but it is most unlikely that these were directly responsible for the sudden deaths. Poisoning was suspected but could not be proved. Post-mortem examinations did not provide any clue besides showing that the deaths were due to non-specific causes, pneumonia and enteritis. All surviving pigs in block 4, which were nearly of bacon weight, were slaughtered as a precautionary measure, and only three pigs remained in block 5. It was, therefore, decided not to include the incomplete records of these animals in the present paper. Thus the results are based on the first three blocks only, i.e. each of the treatments was replicated three times.

Table 3 gives details of growth and food consumption of the pigs in these three blocks. The pigs which received the normal fish-meal diet and the yeast diet supplemented with irradiated yeast (diets 3 and 6 ) appeared normal. They consumed their food readily; their daily live-weight gain and food utilization were as good as could be expected from the wartime quality of the feeding-stuffs which made up their rations.

On the other hand, the behaviour of some of the pigs which received the other four diets was obviously abnormal. In block I the pigs receiving the yeast diet (diet I), the 
Vol. 2

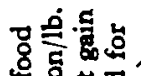

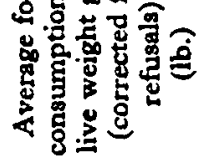

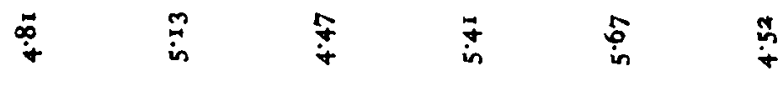

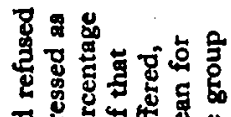

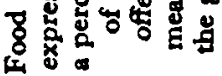

$\hat{i} \quad \dot{q} \quad \dot{0} \quad \stackrel{\infty}{\infty} \quad \stackrel{i}{i} \quad \overrightarrow{0}$

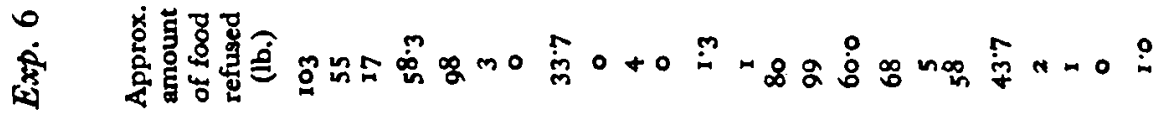

.

.

密

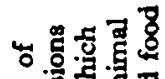

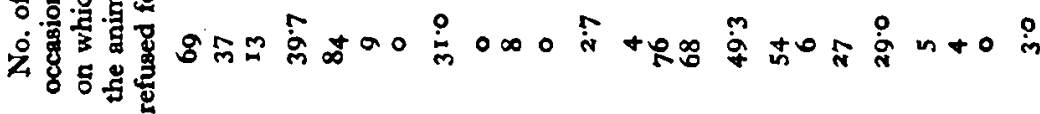

\$

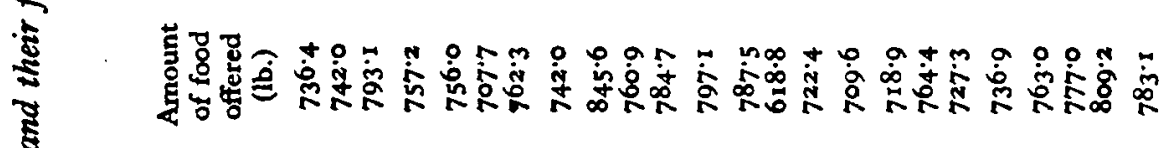

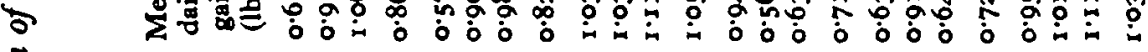

莡

సั้

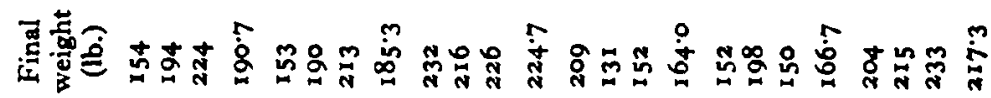

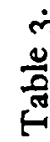

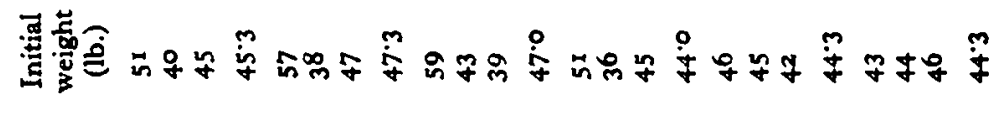

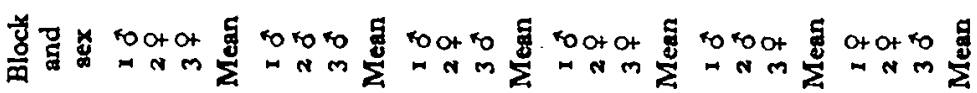

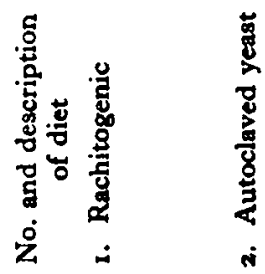

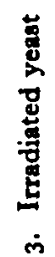

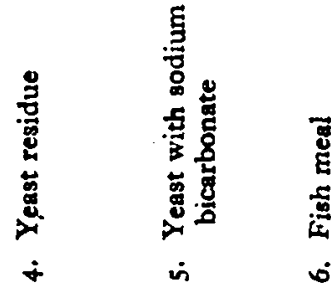


autoclaved yeast diet (diet 2 ) and the diet with sodium bicarbonate (diet 5 ) developed symptoms of rickets similar to those observed in previous experiments. Their liveweight gain and food utilization were subnormal and they refused food on many occasions. The pig receiving the yeast-residue diet (diet 4 ) grew at a normal rate.

Table 4. $\mathrm{pH}$ of intestinal contents of two blocks of pigs in Exp. 6

$\begin{array}{ccc}\text { Diet } & \text { Block I } & \text { Block 2 } \\ \text { I } & 6.80 & 7.50 \\ 2 & 7.13 & 7.45 \\ 3 & 6.86 & 7.60 \\ 4 & 6.88 & 7.60 \\ 5 & 6.97 & 7.42 \\ 6 & 6.91 & 7.68\end{array}$

Table 5. Calcium content of the blood serum of pigs in Exp. 6

\begin{tabular}{|c|c|c|c|c|}
\hline $\begin{array}{c}\text { No. and description } \\
\text { of diet }\end{array}$ & $\begin{array}{l}\text { Block } \\
\text { and sex }\end{array}$ & $\begin{array}{c}\text { Initial } \\
\text { value } \\
\text { (mg./100 } \mathrm{ml} .)\end{array}$ & $\begin{array}{l}\text { Value after } \\
\text { I2 weeks } \\
\text { (mg./100 ml.) }\end{array}$ & $\begin{array}{l}\text { Value after } \\
24 \text { weeks } \\
\text { (mg./100 ml.) }\end{array}$ \\
\hline \multirow[t]{2}{*}{ I. Rachitogenic } & $\begin{array}{ll}1 & 0 \\
2 & 9 \\
3 & 9\end{array}$ & $\begin{array}{l}10.56 \\
11.49 \\
10.64\end{array}$ & $\begin{array}{r}7.05 \\
10.57 \\
9.98\end{array}$ & $\begin{array}{l}6 \cdot 04 \\
7 \cdot 43 \\
9 \cdot 25\end{array}$ \\
\hline & Mean & 10.90 & $9 \cdot 20$ & $7 \cdot 57$ \\
\hline \multirow[t]{2}{*}{ 2. Autoclaved yeast } & 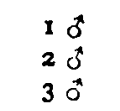 & $\begin{array}{l}11 \cdot 32 \\
10 \cdot 25 \\
10 \cdot 43\end{array}$ & $\begin{array}{r}7.54 \\
10.09 \\
10.28\end{array}$ & $\begin{array}{r}7.65 \\
10.55 \\
11.69\end{array}$ \\
\hline & Mean & 10.67 & $9 \cdot 30$ & $9 \cdot 96$ \\
\hline \multirow[t]{3}{*}{ 3. Irradiated yeast } & $\begin{array}{l}10 \\
20\end{array}$ & $\begin{array}{l}10 \cdot 87 \\
11 \cdot 10\end{array}$ & $\begin{array}{l}10 \cdot 52 \\
10 \cdot 30\end{array}$ & $\begin{array}{l}10.91 \\
10.98\end{array}$ \\
\hline & 39 & 10.55 & 10.68 & II 75 \\
\hline & Mean & 10.84 & 10.50 & II 21 \\
\hline \multirow[t]{2}{*}{ 4. Yeast residue } & $\begin{array}{l}10 \\
29 \\
39\end{array}$ & $\begin{array}{l}11 \cdot 45 \\
10 \cdot 77 \\
10.78\end{array}$ & $\begin{array}{l}9 \cdot 95 \\
8 \cdot 00 \\
5 \cdot 87\end{array}$ & $\begin{array}{r}10.17 \\
7.49 \\
6.60\end{array}$ \\
\hline & Mean & $11 \cdot \infty$ & $7 \cdot 94$ & 8.09 \\
\hline \multirow[t]{2}{*}{ 5. Yeast with sodium bicarbonate } & $\begin{array}{l}10 \\
20 \\
30\end{array}$ & $\begin{array}{l}10 \cdot 20 \\
11 \cdot 14 \\
13 \cdot 25\end{array}$ & $\begin{array}{r}7 \cdot 16 \\
10.81 \\
10.48\end{array}$ & $\begin{array}{r}7 \cdot 26 \\
9.85 \\
10.29\end{array}$ \\
\hline & Mean & 10.86 & $9 \cdot 48$ & $9 \cdot 13$ \\
\hline \multirow[t]{2}{*}{ 6. Fish meal } & $\begin{array}{l}19 \\
29 \\
30\end{array}$ & $\begin{array}{l}11 \cdot 21 \\
11 \cdot 37 \\
10.89\end{array}$ & $\begin{array}{l}11 \cdot 08 \\
11 \cdot 12 \\
10 \cdot 00\end{array}$ & $\begin{array}{l}11 \cdot 26 \\
11.84 \\
11 \cdot 55\end{array}$ \\
\hline & Mean & $11 \cdot 16$ & 10.73 & $11 \cdot 55$ \\
\hline
\end{tabular}

In block 2 none of the pigs showed definite symptoms of rickets. The pigs receiving diets $I$ and 5 refused food in the later stages of the experiment, while the pig receiving diet 4 refused food throughout the experimental period and grew at a slow rate, but showed no other abnormal symptoms. The pig receiving diet 2 grew at an irregular rate but otherwise appeared normal.

In block 3 only pigs receiving diets 4 and 5 definitely deviated from normal. They grew slowly and frequently refused fód, but no other symptoms were observed.

The $\mathrm{pH}$ of the intestinal contents of the pigs in the two blocks tested was not affected by the diet (Table 4). Pigs on diets 3 and 6 maintained their serum-calcium level throughout and even showed a slight increase in the final estimation (Table 5). 
On the other hand, the values for all the other pigs declined, especially for the three pigs in block I which showed symptoms of rickets. At the conclusion of the main experiment each of these three animals was given $3^{\circ} \mathrm{g}$. daily of controlled cod-liver oil mixture for a period of 9 weeks and recovered completely.

\section{Analytical methods}

\section{Exp. 7. The effect of yeast on the hydrolysis of phytic acid} in the intestine of the pig

The phytate phosphorus of the diets and faeces was determined by the method of McCance \& Widdowson (1935) as modified by Cruickshank, Duckworth, Kosterlitz $\&$ Warnock (1945). The final phosphorus determinations were done by the strychninemolybdate method described by Peters \& Van Slyke (1932).

Table 6. Percentage composition and phytate phosphorus content of the diets used in Exp. 7

$\begin{array}{lccc}\text { Component } & \begin{array}{c}\text { Normal } \\ \text { fattening } \\ \text { diet }\end{array} & \begin{array}{c}\text { Control } \\ \text { meat meal } \\ \text { diet }\end{array} & \begin{array}{c}\text { Yeast } \\ \text { diet }\end{array} \\ \text { Wheat feed } & 48 & 46 & 40 \\ \text { Barley meal } & 20 & 20 & 18 \\ \text { Maize meal } & 20 & 20 & 18 \\ \text { Meat meal } & - & 10 & - \\ \text { Fish meal } & 10 & - & - \\ \text { Dried grass } & 2 & 2 & 2 \\ \text { Calcium carbonate } & - & 1 \cdot 5 & 1 \cdot 5 \\ \text { Salt } & - & 0.5 & 0.5 \\ \text { Dried brewer's yeast } & - & - & 20 \\ \text { \% phytate P } & 0.38 & 0.38 & 0.32\end{array}$

\section{Experimental details}

Four pairs of litter-mate Large White pigs, 12 weeks old, were divided into two groups of four pigs each. Both groups were given a normal fattening ration for 5 weeks when a composite sample of faeces was taken from each group and analysed for phytate phosphorus. Subsequently one group received a control meat-and-bone meal diet similar to that used previously in this series of experiments (Braude et al. 1943), while the other group was given the $20 \%$ yeast diet. The composition of the diets and their phytate phosphorus contents are given in Table 6 .

When the pigs had been I week on these diets, and again 2 weeks later, samples of faeces were taken from each group and analysed for phytate phosphorus. The diets were given for another month and were then followed for a period of 5 weeks by diets in which the phytase had been destroyed. The diets were fed as a wet mash (Braude et al. 1943) and to destroy the phytase, instead of cold water, boiling water was used for mixing according to the method of Pedersen (1940); the mash was allowed to cool before being given. The phytate phosphorus content of the faeces was determined after $I, 4$ and 5 weeks on these diets. 


\section{Results}

The results of the experiment are given in Table 7. They do not suggest any inhibitory effect of yeast on the intestinal hydrolysis of phytate. On the contrary, pigs receiving yeast excreted no measurable amounts of phytate phosphorus though some was present in their faeces when they were eating the control fattening ration. With the meat-and-bone meal ration, however, more phytate passed through the gut unchanged and it is remarkable that the replacement of $10 \%$ fish meal by $10 \%$ meat-and-bone

Table 7. Phytate phosphorus excretion by groups" of four pigs in Exp. 7

\begin{tabular}{lccc}
\multicolumn{1}{c}{$\begin{array}{c}\text { Length of } \\
\text { time on } \\
\text { diet } \\
\text { (weeks) }\end{array}$} & $\begin{array}{c}\text { Meat-meal } \\
\text { diet group } \\
\text { Phytate P/g. } \\
\text { faeces }\end{array}$ & $\begin{array}{c}\text { Yeast } \\
\text { (miet group } \\
\text { Phytate P/g. } \\
\text { faeces }\end{array}$ \\
Normal fattening. & 5 & 4.4 & 3.2 \\
Experimental & 1 & 1.8 & 0 \\
& 3 & 16.5 & 0 \\
Experimental with phytase destroyed & 1 & 10.4 & 4.9 \\
& 4 & 78.7 & 10.6 \\
& 5 & 82.2 & 13.0
\end{tabular}

meal should have had such a definite effect. In fact the result could be interpreted as indicating inhibition of phytase activity by the meat-and-bone meal. When the phytase in the diet was destroyed, the excretion of phytate phosphorus by both groups of pigs increased, but again much more phytate was found in the faeces of the pigs which received the meat-and-bone meal.

It is clear that these findings neither support our original tentative explanation of the rachitogenic effect of yeast nor agree with the results of Hoff-Jorgensen's (1947) tests in vitro. A repetition of his tests with the yeast used in the pig experiment seemed, therefore, desirable.

Exp. 8. The effect of fresh and dried brewer's yeast and of fresh baker's yeast on the hydrolysis, in vitro, of sodium phytate by wheat phytase

\section{Method of measurement}

The effect of yeast on the hydrolysis of solutions of pure sodium phytate was determined by a method essentially that of Hoff-Jørgensen (1947). The phytase solution was prepared by shaking wheat bran for $2 \mathrm{hr}$. with ten times its weight of water; it was then filtered through muslin and toluene was added as a preservative.

To a suitable amount of sodium phytate in a $250 \mathrm{ml}$. centrifuge tube, $50 \mathrm{ml}$. of the phytase solution were added, followed by $0.2 \mathrm{M}$-acetate buffer to give the desired volume (about $100 \mathrm{ml}$.). In experiments with yeast it was shaken for I hr. with $50 \mathrm{ml}$. of the acetate buffer and the sodium phytate and the phytase solution were then added. In all cases the $\mathrm{pH}$ of the final system was adjusted to 5.20 . The tubes were incubated for $2 \mathrm{hr}$. at $30^{\circ}$. After incubation $10 \mathrm{ml}$. of solution were removed from each tube and 
were replaced by $10 \mathrm{ml}$. of $5 \mathrm{~N}-\mathrm{HCl}$ to stop the hydrolysis. After centrifuging, the phytate phosphorus was measured in the supernatant liquid.

\section{Yeasts tested}

Dried brewer's yeast, fresh brewer's yeast (from Messrs H. and G. Simonds, Reading) as received from the brewery, washed brewer's yeast, i.e. fresh brewer's yeast filtered on a Buchner funnel and washed with water in order to remove the beer residues, and fresh baker's yeast were used.

\section{Table 8. The hydrolysis of sodium phytate by wheat phytase in the presence or absence of yeast}

Unless otherwise stated sodium phytate was incubated with phytase for $2 \mathrm{hr}$. at $30^{\circ}$ and $\mathbf{p H} 5.2$.

\begin{tabular}{|c|c|c|c|c|c|}
\hline \multirow[b]{2}{*}{ Exp. } & \multirow[b]{2}{*}{ Addition } & \multicolumn{3}{|c|}{ Phytate phosphorus } & \multirow[b]{2}{*}{ Inhibition } \\
\hline & & $\begin{array}{l}\text { Originally } \\
\text { present } \\
\text { (mg.) }\end{array}$ & $\begin{array}{l}\text { Split } \\
\text { (mg.) }\end{array}$ & $\begin{array}{c}\text { Hydrolysis } \\
(\%)\end{array}$ & \\
\hline I & $\begin{array}{l}\text { None } \\
\text { I g. dried brewer's yeast } \\
5 \text { g. fresh brewer's yeast" }\end{array}$ & $\begin{array}{l}5 x \cdot 4 \\
5 I \cdot 4 \\
5 I \cdot 4\end{array}$ & $\begin{array}{l}26 \cdot 0 \\
28 \cdot 9 \\
29 \cdot 5\end{array}$ & $\begin{array}{l}50 \cdot 6 \\
56 \cdot 2 \\
57 \cdot 4\end{array}$ & $\begin{array}{l}- \\
0 \\
0\end{array}$ \\
\hline 2 & $\begin{array}{l}\text { None } \\
5 \mathrm{~g} \text {. fresh brewer's yeast* } \\
5 \mathrm{~g} \text {. fresh brewer's yeast, } \\
\text { washed } \dagger\end{array}$ & $\begin{array}{l}5 I \cdot 4 \\
5 I \cdot 4 \\
5 I \cdot 4\end{array}$ & $\begin{array}{l}28 \cdot 2 \\
31 \cdot 1 \\
29 \cdot 2\end{array}$ & $\begin{array}{l}54 \cdot 9 \\
60 \cdot 5 \\
56 \cdot 8 \\
62 \cdot 8\end{array}$ & $\begin{array}{l}- \\
0 \\
0\end{array}$ \\
\hline 3 & $\begin{array}{l}\text { None } \\
5 \mathrm{~g} \text {. dried brewer's yeast } \\
10 \mathrm{~g} \text {. fresh baker's yeast }\end{array}$ & $\begin{array}{l}51 \cdot 4 \\
46 \cdot 9 \\
46 \cdot 9 \\
46 \cdot 9\end{array}$ & $\begin{array}{l}32 \cdot 3 \\
25 \cdot 2 \\
28 \cdot 4 \\
26 \cdot 4\end{array}$ & $\begin{array}{l}02 \cdot 8 \\
53 \cdot 7 \\
60 \cdot 5 \\
56 \cdot 3\end{array}$ & $\begin{array}{l}0 \\
0 \\
0\end{array}$ \\
\hline 4 & $\begin{array}{l}\text { None } \\
\text { No enzyme }\end{array}$ & $\begin{array}{l}43 \cdot 5 \\
43.5\end{array}$ & $\begin{array}{r}19.1 \\
6.6\end{array}$ & $\begin{array}{l}43 \cdot 9 \\
15 \cdot 2\end{array}$ & - \\
\hline 5 & $\begin{array}{l}\text { None } \\
\text { No enzyme }\end{array}$ & $\begin{array}{l}47 \cdot 3 \\
47 \cdot 3\end{array}$ & $\begin{array}{r}23 \cdot 3 \\
7 \cdot 4\end{array}$ & $\begin{array}{l}49 \cdot 3 \\
15 \cdot 6\end{array}$ & - \\
\hline
\end{tabular}

Results

The results of this experiment are given in Table 8. They show that yeast, whether fresh or dried, does not inhibit, in vitro, the hydrolysis of sodium phytate by a preparation of wheat phytase. If anything, the breakdown was rather more pronounced in the presence of the yeast.

\section{DISCUSSION}

The outcome of these experiments is essentially negative in that they give little clue to the nature of the rachitogenic factor in yeast. Its presence in autoclaved yeast indicates that it is stable to heat. Whatever the mode of action of yeast it is clear that the attractive suggestion that it acts by inhibiting the breakdown of phytic acid (cf. p. 66) is fallacious. It seems clear that most of the phosphorus present in the yeast diet must be available to pigs. As a matter of fact the phytic acid was more completely hydrolysed in the gut with the yeast diet than with the meat-and-bone meal diet. The difference 
became more marked after treatment of the diet with boiling water suggesting, perhaps, greater heat stability of the phytase in the presence of yeast. Previous work (Braude et al. 1944) showed that the replacement in our pig diets of yeast phosphorus by phosphorus as inorganic phosphate in quantities in excess of those supplied by yeast, did not lead to rickets. A study of the effect of yeast on the metabolism of calcium and phosphorus is clearly needed, but facilities for this type of work are, for the present, not available here.

The addition of sodium bicarbonate to the yeast diets did not prevent the appearance of rickets, thus showing that the protective value of calcium carbonate (Braude et al. 1943, 1944) lies in the calcium moiety. The observation that the inclusion of a small proportion of irradiated yeast makes large amounts of yeast innocuous to the pig may be of practical value, but merely confirms the previous knowledge about the protective action of vitamin $\mathrm{D}$.

From a practical point of view the use of yeast in pig diets presents no problem (Braude et al. 1943), but the theoretical aspect of its rachitogenic effect is, to us, still obscure.

\section{SUMMARY}

1. Three further experiments on the nature of the factor in yeast rachitogenic to pigs (Braude et al. 1943, 1944) have yielded essentially negative results.

2. The factor is heat stable, as it is present in autoclaved yeast.

3. The addition to the rachitogenic diet of $2 \mathrm{~g} . / \mathrm{pig}$ daily of irradiated yeast prevented the occurrence of rickets.

4. The addition to the rachitogenic diet of $2.5 \%$ sodium bicarbonate failed to prevent rickets, showing that the protective value of calcium carbonate (Braude et al. 1943, 1944) was due to calcium per se and not to the alkaline nature of the addition.

5. The feeding of the residue from the preparation of a yeast extract gave inconclusive results.

6. Experiments with pigs disproved our tentative assumption that dried yeast caused rickets by inhibiting the intestinal breakdown of the phytic acid of the diet. In agreement with this, but contrary to the finding of Hoff-Jørgensen (1947), in vitro tests did not show any inhibition of phytase activity by dried yeast.

Our best thanks are due to $\mathrm{Mr}$ A. C. Dunkin for much help in the carrying out of experiment 7; to Dr S. J. Rowland and members of the Chemistry Department who carried out the analyses of the feeding stuffs; to Mr S. C. Watson for the serum calcium estimations and to Misses J. Wagnell and V. Glover for help with the determination of phytate phosphorus. We are grateful to Messrs H. and G. Simonds Ltd., Reading, for the gift of fresh brewer's yeast, and to Messrs Phillips Yeast Products Ltd., London, for the gift of yeast residue. 


\section{REFERENCES}

Booth, R. G. (1934). An Investigation into the Antirachitic Activation of Milk by the Feeding of Irradiated Yeast and Cod-liver oil to Dairy Corws. Ph.D. Thesis, University of Reading.

Braude, R., Kon, S. K. \& White, E. G. (1943). Y. comp. Path. 53, 16 I.

Braude, R., Kon, S. K. \& White, E. G. (1944). F. comp. Path. 54, 88.

Clark, E. P. \& Collip, J. B. (1925). F. biol. Chem: 63, 46r.

Cruickshank, E. W. H., Duckworth, J., Kosterlitz, H. W. \& Warnock, G. M. (1945). F. Physiol. $104,41$. Hoff-Jørgensen, E. (1947). Nature, Lond., I59, 99.

Kramer, B. \& Tisdall, F. F. (1921). F. biol. Chem. 47, 475.

McCance, R. A. \& Widdowson, E. M. (1935). Biochem. $\mathscr{F} .29,2694$.

Møllgaard, H. (1946). Biochem. F. 40, 589.

Pedersen, J. G. A. (1940). Beretn. Forsegslab. Kbh. no. 193.

Peters, J. P. \& Van Slyke, D. D. (1932). Quantitative Clinical Chemistry. 2. Methods, p. 868. London: Baillière, Tindall and Cox. 